\title{
SARS-CoV-2 infection in children with febrile neutropenia
}

\author{
Victoria Flores ${ }^{1} \cdot$ Raquel Miranda $^{1} \cdot$ Laura Merino $^{1} \cdot$ Carmen González $^{1} \cdot$ Cristina Serrano $^{1} \cdot$ Moises Solano $^{1}$. \\ Jessica Herrera ${ }^{1} \cdot$ Paulina González ${ }^{1} \cdot$ Genesis Ruiz ${ }^{1} \cdot$ Ricardo Saldaña $^{1} \cdot$ Ahtziri Cárdenas $^{1} \cdot$ Lénica A. Chávez-Aguilar $^{1}$ (D)
}

Received: 13 May 2020 / Accepted: 1 June 2020 / Published online: 12 June 2020

(C) Springer-Verlag GmbH Germany, part of Springer Nature 2020

\section{Dear Editor,}

Acute lymphoblastic leukemia (ALL) is the most common type of cancer in children, representing approximately onethird of pediatric cancers. Febrile neutropenia (FN) is the most common and potentially lethal complication in patients undergoing chemotherapy [1]. About half of the children treated with chemotherapy for cancer develop at least one FN episode [2]. The world is currently facing a pandemic caused by a new coronavirus [3] and although SARS-CoV-2 infection appears to be less aggressive in children [4], however, the evolution of COVID-19 in children with cancer is still uncertain. Here, we describe three cases of patients with ALL who presented with FN and COVID-19.

Two patients admitted to the emergency department with a history of ALL and fever (Table 1), the initial complete blood count showed neutropenia $\left(<500\right.$ neutrophils per $\left.\mathrm{mm}^{3}\right)$. Another hospitalized patient presented fever without initial neutropenia (patient 2), however, he developed neutropenia in subsequent days. Patients 1 and 2 were on consolidation therapy for ALL, and they had received chemotherapy drugs in the last 14 days. Patient 3 received daily immunosuppression due to hematopoietic stem cell transplantation.

Patients developed respiratory symptoms after the initial fever, one progressing to respiratory distress (patient 3 ), admitted to the intensive care unit. None of the patients presented gastrointestinal symptoms. The patients had a positive PCR test for SARS-CoV-2. In addition, a simple chest computed tomography was performed, with typical COVID-19 appearance in patients 1 and 3 .

Lénica A. Chávez-Aguilar

lenicachavez@gmail.com

1 Department of Pediatric Hematology, Centro Médico Nacional 20 de Noviembre, ISSSTE, Mexico City, Mexico
No other site of infection was found in our patients, the procalcitonin value did not suggest bacterial infection, and no microorganism was identified on blood cultures. Patients 1 and 2 had a hospital stay of 2 weeks; they remained hospitalized because of the uncertainty regarding their clinical evolution due to the lack of medical reports of COVID-19 in patients with ALL and FN. Patient 3 required invasive mechanical ventilation, furthermore, she deteriorated hemodynamically and presented cardiac arrest that did not respond to cardiopulmonary resuscitation.

Patients 1 and 2 were treated with enoxaparin, even though they did not meet criteria for disseminated intravascular coagulation. This treatment was given due to the multiple alterations in coagulation associated with worse prognosis that have been described in patients with COVID-19 [5, 6]. Our patients presented elevation of D-dimer, which is suggestive of thrombotic activity and severe inflammatory process. Patient 3 did not receive thromboprophylaxis due to severe thrombocytopenia.

We present this first experience in Mexican children with FN and ALL. COVID-19 should be suspected in children with FN even in the absence of other symptoms. The prognosis of these patients remains uncertain and larger series reporting the course of SARS-CoV-2 infection in children with hematooncological diseases are needed to develop specific clinical guidelines.

\section{Compliance with ethical standards}

Conflict of interest The authors declare that they have no conflict of interest.

Ethical approval All procedures performed in studies involving human participants were in accordance with the ethical standards of the institutional committee and with the Helsinki declaration.

Informed consent Informed consent was obtained from all individual participants included in the study. 
Table 1 Characteristics of children with febrile neutropenia and acute lymphoblastic leukemia infected with SARS-CoV-2

\begin{tabular}{|c|c|c|c|c|}
\hline & $\begin{array}{l}\text { Reference } \\
\text { range }\end{array}$ & Patient 1 & Patient 2 & Patient 3 \\
\hline Age (years) & & 9 & 4 & 8 \\
\hline Sex & & Fem & Fem & Fem \\
\hline \multicolumn{5}{|l|}{ Medical history } \\
\hline Conditions & & $\begin{array}{l}\text { ALL in consolidation } \\
\text { therapy }\end{array}$ & $\begin{array}{l}\text { ALL in consolidation } \\
\text { therapy }\end{array}$ & $\begin{array}{l}\text { ALL post-hematopoietic stem cells } \\
\text { transplantation }\end{array}$ \\
\hline Medicaments & & $\begin{array}{l}\text { Cytarabine and } \\
\text { cyclophosphamide }\end{array}$ & $\begin{array}{l}\text { Methotrexate and } \\
\text { mercaptopurine }\end{array}$ & Mycophenolate, prednisone \\
\hline \multicolumn{5}{|l|}{ Values on admission } \\
\hline White cell count (per $\mathrm{mm}^{3}$ ) & & 1000 & 920 & 1300 \\
\hline Neutrophils (per $\mathrm{mm}^{3}$ ) & & 150 & 350 & 475 \\
\hline Lymphocytes (per mm³) & & 510 & 370 & 110 \\
\hline Platelets (per $\mathrm{mm}^{3}$ ) & & 295,000 & 353,000 & 5000 \\
\hline Hemoglobin (gr/dL) & & 8.7 & 11.7 & 8.4 \\
\hline Prothrombin time (second) & & 17 & 11.4 & 11.2 \\
\hline $\begin{array}{l}\text { Activated thromboplastin time } \\
\text { (second) }\end{array}$ & & 26 & 26.8 & 27.2 \\
\hline Fibrinogen (mg/dL) & $199-400$ & 332 & 473 & 406 \\
\hline D-dimer -ng/ml & $100-560$ & 800 & 1700 & 1200 \\
\hline Antithrombin III (U/mL) & $0.90-1.30$ & 0.98 & 1.25 & 0.99 \\
\hline Lactic dehydrogenase & $110-295$ & 717 & 482 & 301 \\
\hline Interleukin $(6 \mathrm{pg} / \mathrm{mL})$ & $0-5.9$ & 41 & - & - \\
\hline Ferritin $(\mathrm{ng} / \mathrm{mL})$ & $7-140$ & 2092 & 2366 & 2190 \\
\hline Procalcitonin $(\mathrm{ng} / \mathrm{mL})$ & $<0.5$ & 0.27 & 0.05 & 0.17 \\
\hline C-reactive protein $(\mathrm{mg} / \mathrm{L})$ & & 1.3 & 500.4 & 110 \\
\hline Antibiotics & & Clarithromycin & Clarithromycin & Clarithromycin \\
\hline Thromboprophylaxis & & Enoxaparin & Enoxaparin & No \\
\hline Survived & & Yes & Yes & No \\
\hline Days of hospital stay & & 14 & 13 & 1 \\
\hline
\end{tabular}

\section{References}

1. Ammann RA, Tissing WJ, Phillips B (2012) Rationalizing the approach to children with fever in neutropenia. Curr Opin Infect Dis 25(3):258-265. https://doi.org/10.1097/QCO.0b013e328351d199

2. Alexander SW, Wade KC, Hibberd PL, Parsons SK (2002) Evaluation of risk prediction criteria for episodes of febrile neutropenia in children with cancer. J Pediatr Hematol Oncol 24(1):38-42

3. Sifuentes-Rodríguez E, Palacios-Reyes D (2020) COVID-19: the outbreak caused by a new coronavirus. Bol Med Hosp Infant Mex 77(2):47-53. https://doi.org/10.24875/BMHIM.20000039

4. Parri N, Lenge M, Buonsenso D (2020) Children with Covid-19 in pediatric emergency departments in Italy. N Engl J Med. https://doi. org/10.1056/NEJMc2007617
5. Tang N, Li D, Wang X, Sun Z (2020) Abnormal coagulation parameters are associated with poor prognosis in patients with novel coronavirus pneumonia. J Thromb Haemost 18(4):844-847. https://doi. org $/ 10.1111 /$ jth. 14768

6. Klok FA, Kruip MJHA, van der Meer NJM, Arbous MS, Gommers DAMPJ, Kant KM, Kaptein FHJ, van Paassen J, Stals MAM, Huisman MV, Endeman H (2020) Incidence of thrombotic complications in critically ill ICU patients with COVID-19. Thromb Res S0049-3848(20):30120-30121. https://doi.org/10.1016/j.thromres. 2020.04.013

Publisher's note Springer Nature remains neutral with regard to jurisdictional claims in published maps and institutional affiliations. 